\title{
Diamond-Like Carbon Nanofoam from Low-Temperature Hydrothermal Carbonization of a Sucrose/Naphthalene Precursor Solution
}

\author{
Natalie Frese ${ }^{1,2}$, Shelby Taylor Mitchell ${ }^{2}$, Amanda Bowers ${ }^{2}$, Armin Gölzhäuser ${ }^{1}$ \\ and Klaus Sattler ${ }^{2, *}$ \\ 1 Faculty of Physics, University of Bielefeld, D-33501 Bielefeld, Germany; natalie.frese@gmx.de (N.F.); \\ ag@uni-bielefeld.de (A.G.) \\ 2 Department of Physics and Astronomy, University of Hawaii, 2505 Correa Road, Honolulu, HI 96822, USA; \\ smitch22@hawaii.edu (S.T.M.); bowersa@hawaii.edu (A.B.) \\ * Correspondence: sattler@hawaii.edu; Tel.: +1-808-856-8941
}

Received: 7 June 2017; Accepted: 30 June 2017; Published: 6 July 2017

\begin{abstract}
Unusual structure of low-density carbon nanofoam, different from the commonly observed micropearl morphology, was obtained by hydrothermal carbonization (HTC) of a sucrose solution where a specific small amount of naphthalene had been added. Helium-ion microscopy (HIM) was used to obtain images of the foam yielding micron-sized, but non-spherical particles as structural units with a smooth foam surface. Raman spectroscopy shows a predominant $\mathrm{sp}^{2}$ peak, which results from the graphitic internal structure. A strong $\mathrm{sp}^{3}$ peak is seen in X-ray photoelectron spectroscopy (XPS). Electrons in XPS are emitted from the near surface region which implies that the graphitic microparticles have a diamond-like foam surface layer. The occurrence of separated $\mathrm{sp}^{2}$ and $\mathrm{sp}^{3}$ regions is uncommon for carbon nanofoams and reveals an interesting bulk-surface structure of the compositional units.
\end{abstract}

Keywords: carbon; nanomaterials; nanofoam; nanostructured; porous; ultralight materials; hydrothermal carbonization

\section{Introduction}

A large variety of nanomaterials can be formed from elemental carbon. Amorphous carbon materials with a high fraction of $\mathrm{sp}^{2}$ bonds are named graphite-like carbons. When $\mathrm{sp}^{3}$ bonds are dominating, the materials are named diamond-like carbons. Their properties depend on the relative abundance of the $\mathrm{sp}^{2}$ - and $\mathrm{sp}^{3}$ - hybridized carbon atoms [1]. Carbon materials with both graphite- and diamond-like bonds were realized by various synthetic methods, e.g., laser ablation, chemical vapor deposition or hydrothermal carbonization [2]. For example, a material containing graphene sheets and diamond-like structures has been observed after catalytic carbonization of wood charcoal [3]. In this study, we focus on hydrothermal carbonization (HTC) for the synthesis of carbon nanofoam with separated regions of $\mathrm{sp}^{2}$ - and $\mathrm{sp}^{3}$-hybridized carbon atoms.

Hydrothermal carbonization is a promising method for the synthesis of carbon nanomaterials from biomass [4] for a wide range of applications in fields such as energy storage environment protection [5]. It has been used in industry for the production of fuels and other energetic materials [6]. The carbonization of sucrose biomass usually leads to foam-structured materials consisting of spherical micron-sized particles [7]. It has been shown that a small amount of naphthalene added to a sucrose solution acts as a nucleation seed during the HTC process leading to low density, high-quality carbon foams consisting of micropearls with internal pores [8]. The surface of these materials has been modified by chemical functionalization, and the bulk structure by introducing additional porosity [9]. 
A different morphology has been obtained by adding graphene oxide to biomass, which results in carbon materials with higher degree of carbonization and higher conductivity [10]. Porous carbon structures have also been produced by HTC of crude plant material, which can be up-scaled to large quantities with low cost, and these materials may have industrial applications for catalytic support and for sorption purposes [11]. Other potential applications of carbon nanofoam include hydrogen storage [12], cathodes for batteries [13,14] or composites for electrodes [15,16]. It follows that the HTC method for the synthesis of functional carbon materials can be used for a broad range of applications [2].

For this study, we produced carbon nanofoam by naphthalene-assisted hydrothermal carbonization of sucrose. We find that the amount of added naphthalene critically determines the foam morphology. At low naphthalene concentrations, the foam consists of an agglomeration of porous micropearls [8]. At higher concentration, however, the carbon nanofoam consists of micron-sized irregularly shaped particles with sponge-like surfaces as visualized by helium ion microscopy (HIM). X-ray photoelectron spectroscopy (XPS) reveals a diamond-like carbon surface. The Raman spectrum shows the D and $G$ bands of carbon with a distinctly higher $G$ peak. These results characterize the foam as a material consisting of species with a graphite-like core and a diamond-like shell. The density of the analyzed sample is $0.21 \mathrm{~g} \cdot \mathrm{cm}^{-3}$, far below the density of graphite, due to internal pores.

\section{Results}

\subsection{Microscopy}

Figure 1 displays two helium ion microscopy images of the carbon foam sample. Figure 1a shows one side of a foam particle. The particle has a diameter of about $200 \mu \mathrm{m}$ and a uniform rough surface structure.

A higher-magnification image of the foam particle is presented in Figure 1b. It depicts the upper right part of the particle shown in Figure 1a, and it can be seen that the surface has a sponge-like and frayed character. The sponge-like surface implies a porous foamy structure, which is also indicated by the low density of $0.21 \mathrm{~g} \cdot \mathrm{cm}^{-3}$ of the sample. The edge resolution of the image in Figure $1 \mathrm{~b}$ is around $15 \mathrm{~nm}$, which was determined by the distance between $25 \%$ and $75 \%$ of the maximum intensity of a sharp edge [17].
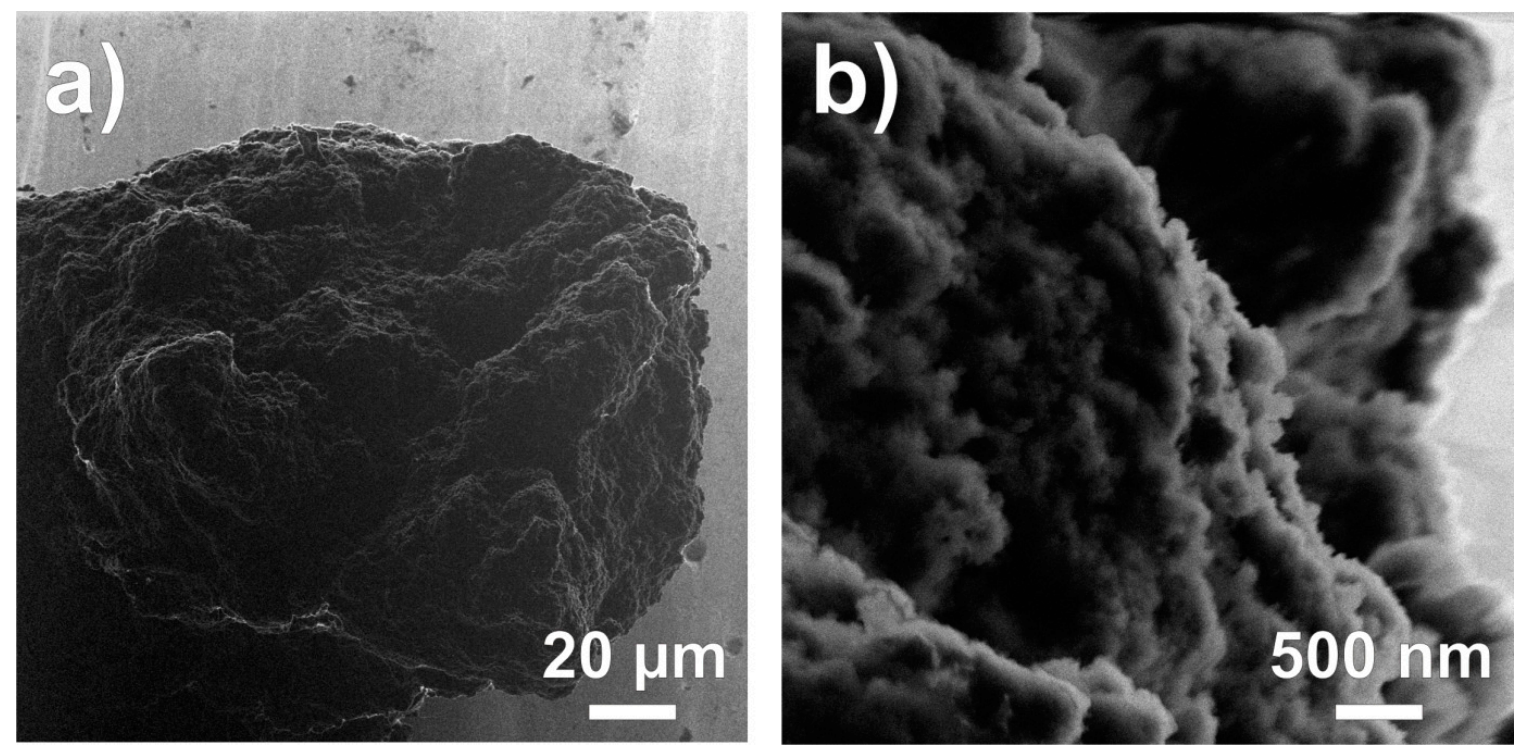

Figure 1. Helium-ion microscopy images of carbon nanofoam, (a) showing a micron-sized part of the foam and (b) showing in higher magnification the sponge-like surface of the foam. 


\subsection{XPS}

The chemical composition of the carbon nanofoam surface was determined by XPS. Figure 2a shows the $\mathrm{C} 1 \mathrm{~s}$ and Figure $2 \mathrm{~b}$ the O1s photoelectron signals of the foam sample. The de-convoluted carbon curve in Figure 2a consists of five peaks, labeled as C1-C5. It has been shown that the $\mathrm{sp}^{3}$-hybridized carbon peak is shifted around $1 \mathrm{eV}$ from the $\mathrm{sp}^{2}$-hybridized carbon peak [18]. Therefore, the two main peaks at $284.4 \mathrm{eV}(\mathrm{C} 1)$ and $285.5 \mathrm{eV}(\mathrm{C} 2)$ are assigned to aromatic and aliphatic carbons, respectively. The $\mathrm{C} 1$ peak has an area of $28 \%$, whereas the C2 peak has an area of $39 \%$. Since XPS is a surface-sensitive method, it follows that the foam surface has a diamond-like composition, because the aliphatic carbons dominate in the spectrum. The remaining three peaks at $286.4 \mathrm{eV}(19 \%)$, $287.3 \mathrm{eV}(10 \%)$ and $289.1 \mathrm{eV}(4 \%)$ are assigned to carbon-oxygen bonds; to hydroxyl, carbonyl and carboxylic groups, respectively [19]. Further surface groups such as carboxylic anhydride, lactone or lactol may also contribute to the carbon-oxygen peaks [20]. The feature at $289.1 \mathrm{eV}$, assigned to $\mathrm{O}=\mathrm{C}-\mathrm{OH}$, could in part be due to $\pi-\pi^{*}$ shape-up satellites associated with electron transitions between the carbon HOMO-LUMO gap. Such satellite peaks have been reported in the literature at $290 \mathrm{eV}$ [21], $\sim 290.5 \mathrm{eV}$ [22], and $291 \mathrm{eV}$ [23].

The O1s curve shows the presence of the oxygenated groups as seen in the C1s spectrum and can be divided into two components, $\mathrm{C}-\mathrm{O}$ bonds at $533.4 \mathrm{eV}$ and $\mathrm{C}=\mathrm{O}$ bonds at $532.1 \mathrm{eV}$, with areas of $62 \%$ and $38 \%$, respectively. We note that no feature is observed at about $536.0 \mathrm{eV}$, where adsorbed water would give a peak in the XPS O1s spectrum [22]. This shows that the water from the aqueous solution has entirely been removed from the samples after extracting from the autoclave and their subsequent thermal treatment. From these various results, we conclude that the surface structure of the nanofoam can be described as a diamond-like open framework decorated with oxygenated functional groups.

a)

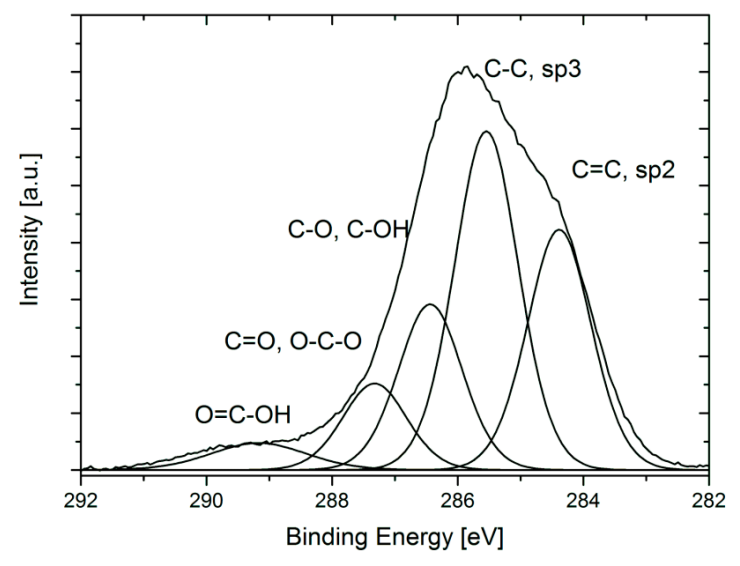

b)

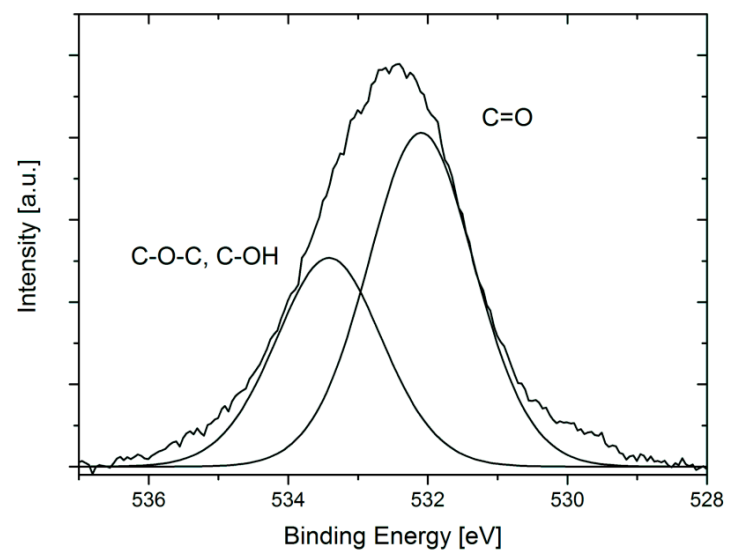

Figure 2. XP spectra of (a) C1s signals, and (b) O1s signals of the carbon nanofoam. 


\subsection{Raman Spectroscopy}

The Raman spectrum shown in Figure 3 exhibits a pattern which is common for carbonized materials [24]. We used a Gaussian two-curve fitting to decompose the main Raman signal into two peaks. The deconvoluted $\mathrm{G}$ peak arises from graphite carbon bond-stretching motion and is located at around $1582 \mathrm{~cm}^{-1}$. The second peak at around $1360 \mathrm{~cm}^{-1}$ is known as the defect-derived $\mathrm{D}$ peak, and is assigned to ring breathing vibrations in benzene [19]. The peak locations are in good agreement with literature values for disordered graphite, where the $G$ peak is usually located at around $1580 \mathrm{~cm}^{-1}$ and the D peak at around $1350 \mathrm{~cm}^{-1}$ [25]. The observed G peak differs from the sharp Raman peak at $1575 \mathrm{~cm}^{-1}$ for perfect graphite [26]. This reveals that the material has a mixed content of aromatic and aliphatic carbons. The measured intensity of the $\mathrm{D}$ band relative to that of the $\mathrm{G}$ band is 0.52 corresponding to the values for disordered graphite, which typically lie between 0.51 and 1.1 [27]. Since the $\mathrm{G}$ band is broader than $45 \mathrm{~cm}^{-1}$ (the value for graphite), the core of the foam appears to be dominated by small aromatic clusters with sizes less than $10 \AA$ [28].

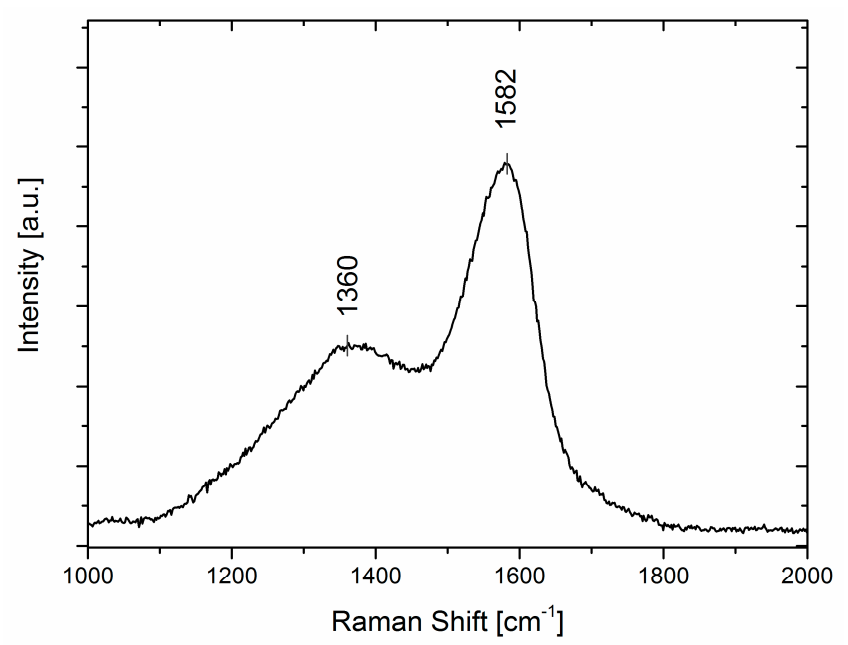

Figure 3. Raman spectrum in the wavenumber range 1000 to $2000 \mathrm{~cm}^{-1}$.

\section{Discussion}

We have confirmed that hydrothermal carbonization is an excellent method for the production of high-quality carbon nanomaterials. It has generally been used in the past in industrial applications such as, for example, the charcoal production from raw cellulosic materials [29], mesoporous carbons from crude plant material [11], or ethanol from biomass [30]. If using natural precursor materials, excessive purification however is usually required. No such purification is necessary if synthetic hydrocarbons are used. Saccharides are among the precursor materials which are non-toxic and easily carbonized without catalysts $[7,19,31]$. Among these, glucose [32,33] and sucrose [8] are convenient precursors.

Many carbonization studies were performed at high temperatures and high pressures (HTHP) [34]. Serp et al. [35], for example, produced carbon nanospheres (CNS) by decomposition of methane at $1100{ }^{\circ} \mathrm{C}$, Wang et al. [36] by the decomposition of benzene at $1000^{\circ} \mathrm{C}$. With the support of catalysts, pentane has been decomposed at $900-1000{ }^{\circ} \mathrm{C}$ [37], anthracene at $900-1000{ }^{\circ} \mathrm{C}$ [38] and camphor at $1000{ }^{\circ} \mathrm{C}[39]$, in all these cases resulting in the synthesis of carbon nanospheres.

With solid-state precursors, process temperatures above and below the critical point of water have been used. For example, the hydrothermal carbonization was performed for cellulose in the 220-250 ${ }^{\circ} \mathrm{C}$ range [40], for glucose between 170 and $500{ }^{\circ} \mathrm{C}$ [19,41-44], for sucrose at $190{ }^{\circ} \mathrm{C}$ [45] and for starch at $600{ }^{\circ} \mathrm{C}$ [46]. Process times were typically between 4 and $12 \mathrm{~h}$. For some of the materials, the graphitic nature has been improved by annealing the sample after synthesis. This typically requires temperatures of up to about $2000{ }^{\circ} \mathrm{C}$ [47]. In this paper, we have shown for naphthalene-assisted 
sucrose carbonization that low process temperature of only $130^{\circ} \mathrm{C}$ combined with a long process time of $72 \mathrm{~h}$ can be used. Even at this low temperature, one obtains complete carbonization, with a high-quality product of uniform morphology and a quite high degree of graphitization.

We also like to note that our use of sucrose as precursor material, without the addition of a catalyst, is a sustainable, bio-based method for the "green" production of carbon materials. Together with the low-temperature and low-pressure process conditions, no toxic byproducts and no necessary pre- or post-purification, it provides an easy and clean way for the production of nanocarbons with promising future applications.

The morphology of the carbon nanofoam obtained in this study is unique. Carbon nanofoams usually consist of agglomerations of porous nano- or micron-sized spheres. Such so-called nanoor micro-pearls have been produced by various methods such as laser ablation [48-50], chemical vapor deposition (CVD) [39,51-60] or hydrothermal carbonization (HTC) [30-33,46,61-67]. In this paper, we show that morphologies other than micropearls can be synthesized just by changing the process parameters. In our previous study, carbon microspheres were formed by using hydrothermal carbonization of a sucrose solution with a trace amount of naphthalene [8]. In the present work, we have increased the naphthalene concentration and the process time which resulted in an entirely different foam morphology. This shows that variations in the process conditions can have a major effect on the outcome of the synthesis.

The diamond-like property of the foams in this study is unique since usually nanoporous carbon materials are rather graphitic [68] or graphenic [69] in nature. This applies to various types of materials such as nanoporous hard carbon microspheres [70], fiber-based nanoporous carbon [71], nanoporous carbon tubes [72], nanoporous carbon films [73] or activated carbon [74]. The graphitic nature, given by $\mathrm{sp}^{2}$ hybridization, provides the large surface area in the interior of the foam scaffold. Also, the $\mathrm{sp}^{2}$-hybridization allows for a large variety of structures typically composed of planar aromatic sixfold rings. In addition, inclusion of pentagons leads to ring structures with positive curvature, inclusion of heptagons to areas with negative curvature. Furthermore, the aromatic graphene sheets can be curved similar to those forming the carbon nanotubes. This can lead to a large variety of graphite-like morphologies with many possible applications. For example, it is responsible for the uptake of molecules such as methane [75], $\mathrm{CO}_{2}$ [76], proteins [77], or heavy metals [78]. Also, catalytic properties of the foam [79], as well as gas- [80] and glucose-sensing properties [81] or photoluminescence [82] are related to a graphitic or graphene-like interior of the foams. In particular, hydrogen storage, long proposed for graphitic carbon materials [83], has recently been considered for nanoporous carbons [84-86]. We note that a strong $\mathrm{sp}^{3}$ contribution, as observed for the nanofoam in this work, will affect the general properties of these foams as well as their possible use in future technologies. New applications may be possible for such diamond-like carbon foams.

Diamond-like features of a carbon nanomaterial in Raman spectra can arise mainly from two different sources; either from $\mathrm{sp}^{3}$-related vibrations due to small regions of crystalline diamond (usually nanodiamonds) [87], or from regions with amorphous $\mathrm{sp}^{3}$-related structures [88]. It has been well documented that diamond films in Raman spectroscopy show a sharp feature at about $1332 \mathrm{~cm}^{-1}$ [88]. These phonon vibrations involve the $\mathrm{sp}^{3}$-hybridized carbon atoms in diamond. Very close to it, a band centered at about $1350 \mathrm{~cm}^{-1}$ is generally associated with $\mathrm{sp}^{3}$ amorphous carbon sites and is called D-band (D standing for "disorder"). The sharp peak of crystalline diamond may be superimposed on the broader amorphous carbon band. However, for a material which contains both, amorphous and nanodiamond regions, or a hybrid combination of both, the two bands usually cannot be distinguished since the difference in location is only a few $\mathrm{cm}^{-1}$. In addition, upon shrinking of the crystal to the nanoscale, major changes are observed in the Raman response of nanodiamonds: compared to bulk diamond, the nanodiamond peak is shifted to lower frequencies and appears broadened, sometimes with an asymmetry [89-91]. The phonon confinement effect is mainly considered as the physical origin for these changes [92]. In addition, the position and line shape of the Raman bands may also be affected by lattice defects in nanocrystalline areas resulting in phonon scattering as well as by 
strain in the sample. For example, Shin et al. [93] found that the G peak of the Raman spectrum shifts to higher wave numbers with the increase of compressive stress. In our studies, only one band is observed in the wavenumber region where either diamond structures and/or amorphous structures would occur. This is not surprising, since both the close proximity of the $\mathrm{sp}^{3}$ bands for diamond and of the amorphous carbon, as well as the confinement effect for small diamond clusters, leads to the observation of just one band. We conclude that the D peak in the diamond-like foam of our studies, being separated from the $G$ peak and relatively narrow, may be due to an amorphous/nanodiamond hybrid structure.

In our studies, the $\mathrm{sp}^{3}$-related D-band in the Raman spectrum is measured with relatively low intensity but the C1s XPS spectrum shows a strong $\mathrm{sp}^{3}$-contribution. We relate these two results to the different depth of probing the sample. While Raman spectroscopy yields results for the bulk of the sample, XPS is strongly surface-sensitive. Therefore, we conclude that the bulk of the nanofoam of this study is graphitic in nature while the surface is diamond-like. In addition, both the macroscopic appearance and the HIM images reveal the foam structure of surface. In addition, we note that the low value for the mass density indicates that the core of the foam has also porous structure. The combination of the two different properties of core and surface regions may lead to exciting and valuable new applications of this material.

In the XPS O1s spectrum, various functional groups can generally be assigned to the deconvolution peaks [94-96]. In Figure 2, the peak at around $531.3 \mathrm{eV}$ corresponds to $\mathrm{C}=\mathrm{O}$ bonds, and the peak at around $533.5 \mathrm{eV}$ corresponds to $\mathrm{C}-\mathrm{OH}$ and $\mathrm{C}-\mathrm{O}$ bonds. The $\mathrm{C}=\mathrm{O}$ peak dominates in the de-convoluted $\mathrm{O} 1 \mathrm{~s}$ distribution. At binding energies below the $\mathrm{C}=\mathrm{O}$ peak we observe a small peak which may be assigned to quinone, which is expected to give a feature at $530.7 \mathrm{eV}$ [97]. We note that diamond films have been oxidized showing a strong O1s peak in the XPS [98]. The nature of the oxygen surface groups was found to depend on the oxidation process [99]. Surface morphology was found to change upon oxidation leading to lattice reconstruction at the oxygen-terminated diamond surface [100].

For diamond crystal surfaces, adsorbed oxygen exists in several functional surface groups [101]. The carbon-oxygen interaction of the diamond surface has been investigated and the oxidized diamond surface has been found to be hydrophilic [102]. We note that in our sample the $\mathrm{C}=\mathrm{O}$ peak is the strongest peak in the $\mathrm{O} 1 \mathrm{~s}$ envelope. In fact, the $\mathrm{C}=\mathrm{O}$ group has also been found as the dominant functional group in oxidized diamond-like carbon films [103].

At about $535.8 \mathrm{eV}$, a peak would be observed for adsorbed water. However, no feature is seen at this energy which shows that the water from the sucrose solution has successfully been removed after synthesis. For foam structures with closed cavities the water would remain in the sample. However, since no indication for water adsorption is seen in the O1s spectrum, we conclude that the foam consists of an open scaffold able to release enclosed water by heating the sample after removing from the autoclave. Also, this suggests that this material may effectively be used in adsorption applications, since the pores are open to the environment.

We conclude that the carbon nanofoams, synthesized in these studies, have a new morphology with a porous graphitic core and a diamond-like foam surface. These materials may have new and unexpected applications in various fields of technology.

\section{Instruments and Methods}

\subsection{Hydrothermal Synthesis}

A $2 \mathrm{M}$ sucrose solution and $9 \mathrm{mg}$ of naphthalene were filled into a $130 \mathrm{~mL}$ stainless steel autoclave with a head space of $7 \mathrm{~mm}$ and heated at $130^{\circ} \mathrm{C}$. After $72 \mathrm{~h}$, the formed foam was removed from the autoclave, filtered with hot water and dried at room temperature. The resulting mass density of the foam is $0.21 \mathrm{~g} \cdot \mathrm{cm}^{-3}$, calculated using a high-precision balance and a pre-defined volume container. We note that control experiments, where no naphthalene was added, did not result in foam formation. This suggests that naphthalene acts as a nucleation seed for starting the growth of carbon foam. 
The aromatic ring structure of naphthalene induces the formation of the graphitic carbon morphology. Hydrothermal carbonization, however, is a very complex thermodynamic and chemical process with a large variety of intermediate products. From our experimental results, we find that these intermediates may also lead to diamond-like carbon formation.

Hydrothermal carbonization is a thermochemical process where hydrocarbon precursors are transformed into all-carbon materials $[2,9,61]$. Variables such as precursor composition, as well as autoclave temperature, pressure, and process time, critically determine the synthesized carbon morphologies and their functionalities [104]. The reaction mechanisms are complex, and the operational parameters are interconnected [105]. In addition, with higher temperature and pressure, dramatic changes in the properties of water are known to occur. The dielectric constant of water for example can be considerably lower compared to ambient conditions. The water density increases with pressure and becomes an important variable in the hydrothermal reaction process [106]. At temperatures below $300{ }^{\circ} \mathrm{C}$, the carbon materials are mainly produced by dehydration and polymerization [2]. The mild temperature of $130^{\circ} \mathrm{C}$, applied in this work, is far below the critical point of $\mathrm{T}=373^{\circ} \mathrm{C}$, and therefore provides subcritical conditions. At this mild temperature, water is considered as a reacting dehydrating agent. We note that the catalyst-free carbonization under such subcritical water conditions is more environmentally friendly than most of the other production methods for nanocarbon materials [107].

\subsection{Helium Ion Microscopy}

Helium ion microscopy (HIM) imaging [108] was performed with a Carl Zeiss Orion Plus [109,110]. The ion source of the HIM consists of an atomically sharp tip in helium gas, kept at high positive voltage. Field ionization at the tip of the needle combined with an electrostatic ion optics leads to a very bright He ion beam. The instrument was operated at an acceleration voltage of $34.9 \mathrm{keV}$, a beam current of $0.3 \mathrm{pA}$ and a working distance of $10 \mathrm{~mm}$. The images were obtained by detecting secondary electrons [111] with an Everhart-Thornley detector in the line averaging mode. Since we have used an uncoated sample, an electron flood gun was applied during imaging to stabilize charging. Prior to imaging, the foam was mounted on the sample holder with conductive carbon pads.

Compared to the scanning electron microscope (SEM), the helium ion microscope (HIM) can be applied to a smaller probe size and has a larger secondary electron yield [108]. This leads to images with stronger topographic contrast showing finer structures at the surface of the material [112]. HIM imaging is performed by a fine helium ion beam, and either the backscattered He ions or secondary electrons are detected. The exceptional contrast in the secondary electron (SE) images is due to the small surface interaction volume [113]. The escape depth for the emitted secondary electrons is typically in the range of $5-15 \mathrm{~nm}$ for most materials [114]. The HIM provides a stronger surface sensitivity compared to the electron microscope. The HIM also yields images with a better signal-to-noise ratio [115]. Detailed modeling of the HIM image formation with secondary electron analysis has been provided [116]. A focused spot size smaller than $0.25 \mathrm{~nm}$ [117] or $0.3 \mathrm{~nm}$ [118] has been determined for imaging with the HIM in the SE mode.

\subsection{Raman Spectroscopy}

Raman spectra were obtained with a micro Raman spectrometer (Labram Aramis) operated in the backscattering mode. Spectra at $473 \mathrm{~nm}$ were acquired with a $10 \times$ objective and a thermoelectrically-cooled charge-coupled device detector. The foam was mounted on the sample holder with conductive carbon pads.

Oscillating molecules and functional groups have vibrations which correspond to the molecular structure and the microscopic environment. Such spectroscopic fingerprints, provided by Raman spectroscopy, can be used to identify bonding configurations. Bulk crystalline, nanocrystalline, and amorphous structures can usually well be distinguished. For carbon and carbonaceous materials [119], Raman spectroscopy is a valuable method for the distinction between $\mathrm{sp}^{2}$ - and $\mathrm{sp}^{3}$-related bonds as 
well as $\mathrm{sp}^{2} / \mathrm{sp}^{3}$ hybrid structures. It can even differentiate between different $\mathrm{sp}^{2}$ carbon nanostructures such as carbon nanotubes and graphene [120].

\subsection{X-ray Photoelectron Spectroscopy}

X-ray photoelectron spectroscopy (XPS) was performed in a multi-chamber ultra-high vacuum system (Omicron) using a monochromatic X-ray source $(\mathrm{Al} \mathrm{K \alpha})$ and a Sphera electron analyzer with a spectral resolution of $0.9 \mathrm{eV}$. The spectra of the foam were measured at a chamber pressure below $10^{-9} \mathrm{mbar}$ and an emission angle of $20^{\circ}$. The foam was mounted on the sample holder with conductive carbon pads. The spectra curves were fitted with a Shirley background for C1s, a linear background for O1s and symmetrical Voigt functions for both spectra.

XPS has been successfully applied to many different carbon materials [121] such as activated carbon [122], carbon spheres [123], amorphous carbon, nanodiamonds [124], diamond-like carbon films [125], carbon nanotubes [126], or nanoporous carbons [127]. Also, it can be used to study processes such as heat and chemical treatment [128], amorphization [129], electrochemical oxidation [130], or structural deformation [131]. The use of XPS for chemical analysis [128] and bonding [127] is of particular importance for solid-state research.

A characteristic feature of XPS measurements is that the instrument provides near-surface information about a material. The mean escape depth (MED) of photoelectrons is a complex result of various factors [132]. Both elastic [133,134] and inelastic [135] scattering of the photoelectrons determine the surface sensitivity in XPS. The MEDs vary slightly for different materials and obtain values such as $2.3 \mathrm{~nm}$ for polycrystalline silicon [136], $1.2 \mathrm{~nm}$ for germanium [137], 1-3 nm for various carbon materials [138], or 1-2 nm for amorphous carbon [139]. In our studies, we detect O1s in addition to $\mathrm{C} 1 \mathrm{~s}$ photoelectrons. It has been pointed out that the escape depth of $\mathrm{O} 1 \mathrm{~s}$ electrons in photoemission is of the same order as that of C1s [140]. This suggests that the MED in our XPS experiment is 1-2 nm, for photoelectrons from both the carbon and the oxygen core levels.

Acknowledgments: Natalie Frese was supported during parts of this research by a scholarship from the German Academic Exchange Service (DAAD-Doktorandenstipendium).

Author Contributions: Klaus Sattler and Armin Gölzhäuser conceived and designed the experiments; Natalie Frese, Shelby Taylor Mitchell, Amanda Bowers and Klaus Sattler performed the experiments and analyzed the data; Klaus Sattler and Armin Gölzhäuser contributed reagents/materials/analysis tools; Natalie Frese and Klaus Sattler wrote the paper.

Conflicts of Interest: The authors declare no conflict of interest.

\section{References}

1. Robertson, J. Diamond-like amorphous carbon. Mater. Sci. Eng. R Rep. 2002, 37, 129-281. [CrossRef]

2. Hu, B.; Wang, K.; Wu, L.H.; Yu, S.H.; Antonietti, M.; Titirici, M.M. Engineering carbon materials from the hydrothermal carbonization process of biomass. Adv Mater. 2010, 22, 813-828. [CrossRef] [PubMed]

3. Hata, T.; Vystavel, T.; Bronsveld, P.; DeHosson, J.; Kikuchi, H.; Nishimiya, K.; Imamura, Y. Catalytic carbonization of wood charcoal: Graphite or diamond? Carbon 2004, 42, 961-964. [CrossRef]

4. Tekin, K.; Karagoz, S.; Bektas, S. A review of hydrothermal biomass processing. Renew. Sustain. Energy Rev. 2014, 40, 673-687. [CrossRef]

5. Titirici, M.M.; White, R.J.; Falco, C.; Sevilla, M. Black perspectives for a green future: Hydrothermal carbons for environment protection and energy storage. Energy Environ. Sci. 2012, 5, 6796-6822. [CrossRef]

6. Kruse, A.; Funke, A.; Titirici, M.M. Hydrothermal conversion of biomass to fuels and energetic materials. Curr. Opin. Chem. Biol. 2013, 17, 515-521. [CrossRef] [PubMed]

7. Titirici, M.M.; Antonietti, M.; Baccile, N. Hydrothermal carbon from biomass: A comparison of the local structure from poly- to monosaccharides and pentoses/hexoses. Green Chem. 2008, 10, 1204-1212. [CrossRef]

8. Mitchell, S.T.; Frese, N.; Golzhauser, A.; Bowers, A.; Sattler, K. Ultralight carbon nanofoam from naphtalene-mediated hydrothermal sucrose carbonization. Carbon 2015, 95, 434-441. [CrossRef] 
9. Titirici, M.M.; Antonietti, M. Chemistry and materials options of sustainable carbon materials made by hydrothermal carbonization. Chem. Soc. Rev. 2010, 39, 103-116. [CrossRef] [PubMed]

10. Krishnan, D.; Raidongia, K.; Shao, J.J.; Huang, J.X. Graphene oxide assisted hydrothermal carbonization of carbon hydrates. ACS Nano 2014, 8, 449-457. [CrossRef] [PubMed]

11. Titirici, M.M.; Thomas, A.; Yu, S.H.; Muller, J.O.; Antonietti, M. A direct synthesis of mesoporous carbons with bicontinuous pore morphology from crude plant material by hydrothermal carbonization. Chem. Mater. 2007, 19, 4205-4212. [CrossRef]

12. Blinc, R.; Arcon, D.; Umek, P.; Apih, T.; Milia, F.; Rode, A.V. Carbon nanofoam as a potential hydrogen storage material. Phys. Status Solidi B Basic Solid State Phys. 2007, 244, 4308-4310. [CrossRef]

13. Chervin, C.N.; Long, J.W.; Brandell, N.L.; Wallace, J.M.; Kucko, N.W.; Rolison, D.R. Redesigning air cathodes for metal-air batteries using mnox-functionalized carbon nanofoam architectures. J. Power Sources 2012, 207, 191-198. [CrossRef]

14. Chervin, C.N.; Wattendorf, M.J.; Long, J.W.; Kucko, N.W.; Rolison, D.R. Carbon nanofoam-based cathodes for $\mathrm{Li}-\mathrm{O}_{2}$ batteries: Correlation of pore solid architecture and electrochemical performance. J. Electrochem. Soc. 2013, 160, A1510-A1516. [CrossRef]

15. Long, J.W.; Chervin, C.N.; Brandell, N.L.; Wallace, J.M.; Rolison, D.R. Functionalized carbon nanofoam electrode architectures as cathodes for Zn-air and Li-air batteries. Abstr. Pap. Am. Chem. Soc. 2011, 241.

16. Spanakis, E.; Pervolaraki, M.; Giapintzakis, J.; Katsarakis, N.; Koudoumas, E.; Vernardou, D. Effect of gold and silver nanoislands on the electrochemical properties of carbon nanofoam. Electrochim. Acta 2013, 111, 305-313. [CrossRef]

17. Boden, S.A.; Asadollahbaik, A.; Rutt, H.N.; Bagnall, D.M. Helium ion microscopy of lepidoptera scales. Scanning 2012, 34, 107-120. [CrossRef] [PubMed]

18. Jackson, S.T.; Nuzzo, R.G. Determining hybridization differences for amorphous-carbon from the XPS c-1s envelope. Appl. Surf. Sci. 1995, 90, 195-203. [CrossRef]

19. Sevilla, M.; Fuertes, A.B. Chemical and structural properties of carbonaceous products obtained by hydrothermal carbonization of saccharides. Chem. A Eur. J. 2009, 15, 4195-4203. [CrossRef] [PubMed]

20. Boehm, H.P. Surface oxides on carbon and their analysis: A critical assessment. Carbon 2002, 40, 145-149. [CrossRef]

21. Darmstadt, H.; Roy, C.; Kaliaguine, S.; Choi, S.J.; Ryoo, R. Surface chemistry of ordered mesoporous carbons. Carbon 2002, 40, 2673-2683. [CrossRef]

22. Puziy, A.M.; Poddubnaya, O.I.; Socha, R.P.; Gurgul, J.; Wisniewski, M. XPS and NMR studies of phosphoric acid activated carbons. Carbon 2008, 46, 2113-2123. [CrossRef]

23. Blyth, R.I.R.; Buqa, H.; Netzer, F.P.; Ramsey, M.G.; Besenhard, J.O.; Golob, P.; Winter, M. XPS studies of graphite electrode materials for lithium ion batteries. Appl. Surf. Sci. 2000, 167, 99-106. [CrossRef]

24. Cuesta, A.; Dhamelincourt, P.; Laureyns, J.; Martinezalonso, A.; Tascon, J.M.D. Raman microprobe studies on carbon materials. Carbon 1994, 32, 1523-1532. [CrossRef]

25. Ferrari, A.C.; Robertson, J. Interpretation of Raman spectra of disordered and amorphous carbon. Phys. Rev. B 2000, 61, 14095-14107. [CrossRef]

26. Chu, P.K.; Li, L.H. Characterization of amorphous and nanocrystalline carbon films. Mater. Chem. Phys. 2006, 96, 253-277. [CrossRef]

27. Wopenka, B.; Xu, Y.C.; Zinner, E.; Amari, S. Murchison presolar carbon grains of different density fractions: A Raman spectroscopic perspective. Geochim. Cosmochim. Acta 2013, 106, 463-489. [CrossRef]

28. Schwan, J.; Ulrich, S.; Batori, V.; Ehrhardt, H.; Silva, S.R.P. Raman spectroscopy on amorphous carbon films. J. Appl. Phys. 1996, 80, 440-447. [CrossRef]

29. Guiotoku, M.; Rambo, C.R.; Hotza, D. Charcoal produced from cellulosic raw materials by microwave-assisted hydrothermal carbonization. J. Therm. Anal. Calorim. 2014, 117, 269-275. [CrossRef]

30. Kumar, S.; Kothari, U.; Kong, L.Z.; Lee, Y.Y.; Gupta, R.B. Hydrothermal pretreatment of switchgrass and corn stover for production of ethanol and carbon microspheres. Biomass Bioenergy 2011, 35, 956-968. [CrossRef]

31. Ryu, J.; Suh, Y.W.; Suh, D.J.; Ahn, D.J. Hydrothermal preparation of carbon microspheres from mono-saccharides and phenolic compounds. Carbon 2010, 48, 1990-1998. [CrossRef]

32. Li, T.; Shen, J.F.; Li, N.; Ye, M.X. Facile and novel hydrothermal preparation of functionalised carbon microspheres from glucose by using graphene sheets as a substrate. Mater. Lett. 2012, 89, 202-205. [CrossRef] 
33. Liu, J.; Tian, P.; Ye, J.W.; Zhou, L.; Gong, W.T.; Lin, Y.; Ning, G.L. Hydrothermal synthesis of carbon microspheres from glucose: Tuning sphere size by adding oxalic acid. Chem. Lett. 2009, 38, 948-949. [CrossRef]

34. Bazargan, A.; Yan, Y.; Hui, C.W.; McKay, G. A review: Synthesis of carbon-based nano and micro materials by high temperature and high pressure. Ind. Eng. Chem. Res. 2013, 52, 12689-12702. [CrossRef]

35. Serp, P.; Feurer, R.; Kalck, P.; Kihn, Y.; Faria, J.L.; Figueiredo, J.L. A chemical vapour deposition process for the production of carbon nanospheres. Carbon 2001, 39, 621-626. [CrossRef]

36. Wang, P.; Wei, J.Y.; Huang, B.B.; Qin, X.Y.; Yao, S.S.; Zhang, Q.; Wang, Z.Y.; Xu, G.G.; Jing, X.Y. Synthesis and characterization of carbon spheres prepared by chemical vapour deposition. Mater. Lett. 2007, 61, 4854-4856. [CrossRef]

37. Sharon, M.; Mukhopadhyay, K.; Yase, K.; Ijima, S.; Ando, Y.; Zhao, X.L. Spongy carbon nanobeads-A new material. Carbon 1998, 36, 507-511. [CrossRef]

38. Hou, H.Q.; Schaper, A.K.; Weller, F.; Greiner, A. Carbon nanotubes and spheres produced by modified ferrocene pyrolysis. Chem. Mater. 2002, 14, 3990-3994. [CrossRef]

39. Liu, X.Y.; Huang, B.C.; Coville, N.J. The Fe(CO) 5 catalyzed pyrolysis of pentane: Carbon nanotube and carbon nanoball formation. Carbon 2002, 40, 2791-2799. [CrossRef]

40. Sevilla, M.; Fuertes, A.B. The production of carbon materials by hydrothermal carbonization of cellulose. Carbon 2009, 47, 2281-2289. [CrossRef]

41. Qi, X.H.; Lian, Y.F.; Yan, L.L.; Smith, R.L. One-step preparation of carbonaceous solid acid catalysts by hydrothermal carbonization of glucose for cellulose hydrolysis. Catal. Commun. 2014, 57, 50-54. [CrossRef]

42. Li, M.; Li, W.; Liu, S.X. Hydrothermal synthesis, characterization, and $\mathrm{KOH}$ activation of carbon spheres from glucose. Carbohydr. Res. 2011, 346, 999-1004. [CrossRef] [PubMed]

43. Mi, Y.Z.; Hu, W.B.; Dan, Y.M.; Liu, Y.L. Synthesis of carbon micro-spheres by a glucose hydrothermal method. Mater. Lett. 2008, 62, 1194-1196. [CrossRef]

44. Yi, Z.H.; Liang, Y.G.; Lei, X.F.; Wang, C.W.; Sun, J.T. Low-temperature synthesis of nanosized disordered carbon spheres as an anode material for lithium ion batteries. Mater. Lett. 2007, 61, 4199-4203. [CrossRef]

45. Wang, Q.; Li, H.; Chen, L.Q.; Huang, X.J. Monodispersed hard carbon spherules with uniform nanopores. Carbon 2001, 39, 2211-2214. [CrossRef]

46. Zheng, M.T.; Liu, Y.L.; Xiao, Y.; Zhu, Y.; Guan, Q.; Yuan, D.S.; Zhang, J.X. An easy catalyst-free hydrothermal method to prepare monodisperse carbon microspheres on a large scale. J. Phys. Chem. C 2009, 113, 8455-8459. [CrossRef]

47. Chang, J.C.; Tzeng, Y.F.; Chen, J.M.; Chiu, H.T.; Lee, C.Y. Carbon nanobeads as an anode material on high rate capability lithium ion batteries. Electrochim. Acta 2009, 54, 7066-7070. [CrossRef]

48. Kohno, H.; Tatsutani, K.; Ichikawa, S. Carbon nanofoam formed by laser ablation. J. Nanosci. Nanotechnol. 2012, 12, 2844-2848. [CrossRef] [PubMed]

49. Rode, A.V.; Elliman, R.G.; Gamaly, E.G.; Veinger, A.I.; Christy, A.G.; Hyde, S.T.; Luther-Davies, B. Electronic and magnetic properties of carbon nanofoam produced by high-repetition-rate laser ablation. Appl.Surf. Sci. 2002, 197, 644-649. [CrossRef]

50. Rode, A.V.; Gamaly, E.G.; Christy, A.G.; Gerald, J.F.; Hyde, S.T.; Elliman, R.G.; Luther-Davies, B.; Veinger, A.I.; Androulakis, J.; Giapintzakis, J. Strong paramagnetism and possible ferromagnetism in pure carbon nanofoam produced by laser ablation. J. Magn. Magn. Mater. 2005, 290, 298-301. [CrossRef]

51. Carrasco, J.A.; Prima-Garcia, H.; Romero, J.; Hernandez-Saz, J.; Molina, S.I.; Abellan, G.; Coronado, E. CVD synthesis of carbon spheres using NiFe-LDHs as catalytic precursors: Structural, electrochemical and magnetoresistive properties. J. Mater. Chem. C 2016, 4, 440-448. [CrossRef]

52. Levesque, A.; Binh, V.T.; Semet, V.; Guillot, D.; Fillit, R.Y.; Brookes, M.D.; Nguyen, T.P. Monodisperse carbon nanopearls in a foam-like arrangement: A new carbon nano-compound for cold cathodes. Thin Solid Films 2004, 464, 308-314. [CrossRef]

53. Ma, A.L.; Wang, X.M.; Li, T.B.; Liu, X.G.; Xu, B.S. Characteristics of carbon microspheres and study on its adsorption isotherms. Mater. Sci. Eng. A 2007, 443, 54-59.

54. Mondal, K.C.; Strydom, A.M.; Tetana, Z.; Mhlanga, S.D.; Witcomb, M.J.; Havel, J.; Erasmus, R.M.; Coville, N.J. Boron-doped carbon microspheres. Mater. Chem. Phys. 2009, 114, 973-977. [CrossRef]

55. Pradhan, D.; Sharon, M. Carbon nanotubes, nanofilaments and nanobeads by thermal chemical vapor deposition process. Mater. Sci. Eng. B 2002, 96, 24-28. [CrossRef] 
56. Shi, J.L.; Peng, H.J.; Zhu, L.; Zhu, W.C.; Zhang, Q. Template growth of porous graphene microspheres on layered double oxide catalysts and their applications in lithium-sulfur batteries. Carbon 2015, 92, 96-105. [CrossRef]

57. Vieira, S.M.C.; Rego, C.A.; Birkett, P.R. Carbon spheres formed by hot filament chemical vapour deposition. Diam. Relat. Mat. 2008, 17, 100-104. [CrossRef]

58. Wang, Z.L.; Kang, Z.C. Pairing of pentagonal and heptagonal carbon rings in the growth of nanosize carbon spheres synthesized by a mixed-valent oxide-catalytic carbonization process. J. Phys. Chem. 1996, 100, 17725-17731. [CrossRef]

59. Wright, W.P.; Marsicano, V.D.; Keartland, J.M.; Erasmus, R.M.; Dube, S.M.A.; Coville, N.J. The electrical transport properties of nitrogen doped carbon microspheres. Mater. Chem. Phys. 2014, 147, 908-914. [CrossRef]

60. Zhong, Z.Y.; Chen, H.Y.; Tang, S.B.; Ding, J.; Lin, J.Y.; Tan, K.L. Catalytic growth of carbon nanoballs with and without cobalt encapsulation. Chem. Phys. Lett. 2000, 330, 41-47. [CrossRef]

61. Wohlgemuth, S.A.; Vilela, F.; Titirici, M.M.; Antonietti, M. A one-pot hydrothermal synthesis of tunable dual heteroatom-doped carbon microspheres. Green Chem. 2012, 14, 741-749. [CrossRef]

62. Chen, J.Z.; Chen, Z.H.; Wang, C.H.; Li, X.D. Calcium-assisted hydrothermal carbonization of an alginate for the production of carbon microspheres with unique surface nanopores. Mater. Lett. 2012, 67, 365-368. [CrossRef]

63. Qi, X.H.; Li, L.Y.; Tan, T.F.; Chen, W.T.; Smith, R.L. Adsorption of 1-butyl-3-methylimidazolium chloride ionic liquid by functional carbon microspheres from hydrothermal carbonization of cellulose. Environ. Sci. Technol. 2013, 47, 2792-2798. [CrossRef] [PubMed]

64. Wang, H.L.; Shi, Z.Q.; Jin, J.; Chong, C.B.; Wang, C.Y. Properties and sodium insertion behavior of phenolic resin-based hard carbon microspheres obtained by a hydrothermal method. J. Electroanal. Chem. 2015, 755, 87-91. [CrossRef]

65. Wu, Q.; Li, W.; Tan, J.; Wu, Y.J.; Liu, S.X. Hydrothermal carbonization of carboxymethylcellulose: One-pot preparation of conductive carbon microspheres and water-soluble fluorescent carbon nanodots. Chem.Eng. J. 2015, 266, 112-120. [CrossRef]

66. Zheng, M.T.; Xiao, Y.; Zhang, H.R.; Dong, H.W.; Gong, X.B.; Xu, R.C.; Lei, B.F.; Liu, Y.L.; Liu, X.T. Hydrothermal synthesis and characterization of sulfur-doped carbon microspheres. Chin. J. Inorg. Chem. 2013, 29, 1391-1399.

67. Zhou, X.; You, S.J.; Wang, X.H.; Gan, Y.; Zhong, Y.J.; Ren, N.Q. Hydrothermal synthesis of magnetic carbon microspheres for effective adsorption of CD(II) in water. J. Chem. Technol. Biotechnol. 2014, 89, 1051-1059. [CrossRef]

68. Zhang, Z.J.; Wang, Q.; Zhu, Y.Q.; Chen, X.Y. Nanoporous graphitic carbon materials: Systematic incorporation of $\mathrm{p}-/ \mathrm{m}$-/o-nitroaniline as effective redox additives for largely improving the capacitive performance. Carbon 2016, 100, 564-577. [CrossRef]

69. Dyjak, S.; Kicinski, W.; Norek, M.; Huczko, A.; Labedz, O.; Budner, S.; Polanski, M. Hierarchical, nanoporous graphenic carbon materials through an instant, self-sustaining magnesiothermic reduction. Carbon 2016, 96, 937-946. [CrossRef]

70. Jafari, S.M.; Khosravi, M.; Mollazadeh, M. Nanoporous hard carbon microspheres as anode active material of lithium ion battery. Electrochim. Acta 2016, 203, 9-20. [CrossRef]

71. Li, S.Y.; Wang, Y.; Wei, Y.; Zeng, J.; Shi, W.Y.; Wang, Y.W. Preparation and adsorption performance of palm fiber-based nanoporous carbon materials with high specific surface area. J. Porous Mater. 2016, 23, 1059-1064. [CrossRef]

72. Shrestha, L.K.; Shrestha, R.G.; Yamauchi, Y.; Hill, J.P.; Nishimura, T.; Miyazawa, K.; Kawai, T.; Okada, S.; Wakabayashi, K.; Ariga, K. Nanoporous carbon tubes from fullerene crystals as the pi-electron carbon source. Angewa. Chem. Int. Ed. 2015, 54, 951-955. [CrossRef] [PubMed]

73. Jia, L.C.; Lawrence, G.; Balasubramanian, V.V.; Choi, G.; Choy, J.H.; Abdullah, A.M.; Elzatahry, A.; Ariga, K.; Vinu, A. Highly ordered nanoporous carbon films with tunable pore diameters and their excellent sensing properties. Chem. A Eur. J. 2015, 21, 697-703. [CrossRef] [PubMed]

74. Bandosz, T.J. Nanoporous carbons: Looking beyond their perception as adsorbents, catalyst supports and supercapacitors. Chem. Rec. 2016, 16, 205-218. [CrossRef] [PubMed]

75. Ortiz, L.; Kuchta, B.; Firlej, L.; Roth, M.W.; Wexler, C. Methane adsorption in nanoporous carbon: The numerical estimation of optimal storage conditions. Mater. Res. Express 2016, 3, 5. [CrossRef] 
76. Rashidi, A.M.; Kazemi, D.; Izadi, N.; Pourkhalil, M.; Jorsaraei, A.; Ganji, E.; Lotfi, R. Preparation of nanoporous activated carbon and its application as nano adsorbent for $\mathrm{CO}_{2}$ storage. Korean J. Chem. Eng. 2016, 33, 616-622. [CrossRef]

77. Puziy, A.M.; Poddubnaya, O.I.; Derylo-Marczewska, A.; Marczewski, A.W.; Blachnio, M.; Tsyba, M.M.; Sapsay, V.I.; Klymchuk, D.O. Kinetics of protein adsorption by nanoporous carbons with different pore size. Adsorpt. J. Int. Adsorpt. Soc. 2016, 22, 541-552. [CrossRef]

78. Ghiloufi, I.; Khezami, L.; El Mir, L. Nanoporous activated carbon for fast uptake of heavy metals from aqueous solution. Desalination Water Treat. 2015, 55, 935-944. [CrossRef]

79. Li, W.L.; Seredych, M.; Rodriguez-Castellon, E.; Bandosz, T.J. Metal-free nanoporous carbon as a catalyst for electrochemical reduction of $\mathrm{CO}_{2}$ to $\mathrm{CO}$ and $\mathrm{CH}_{4}$. Chemsuschem 2016, 9, 606-616. [CrossRef] [PubMed]

80. Singh, K.; Travlou, N.A.; Bashkova, S.; Rodriguez-Castellon, E.; Bandosz, T.J. Nanoporous carbons as gas sensors: Exploring the surface sensitivity. Carbon 2014, 80, 183-192. [CrossRef]

81. Zhong, C.Y.; Yuan, W.Y.; Kang, Y.J.; Xie, J.L.; Hu, F.X.; Li, C.M. Biomass-derived hierarchical nanoporous carbon with rich functional groups for direct-electron-transfer-based glucose sensing (vol 3, pg 144, 2016). Chemelectrochem 2016, 3. [CrossRef]

82. Bandosz, T.J.; Rodriguez-Castellon, E.; Montenegro, J.M.; Seredych, M. Photoluminescence of nanoporous carbons: Opening a new application route for old materials. Carbon 2014, 77, 651-659. [CrossRef]

83. Maeland, A.J.; Skjeltorp, A.T. Hydrogen Storage in Carbon Material. U.S. Patent 6,290,753, 18 September 2001.

84. Geng, Z.; Zhang, C.M.; Wang, D.B.; Zhou, X.Y.; Cai, M. Pore size effects of nanoporous carbons with ultra-high surface area on high-pressure hydrogen storage. J. Energy Chem. 2015, 24, 1-8. [CrossRef]

85. Leyva-Garcia, S.; Morallon, E.; Cazorla-Amoros, D.; Beguin, F.; Lozano-Castello, D. New insights on electrochemical hydrogen storage in nanoporous carbons by in situ Raman spectroscopy. Carbon 2014, 69, 401-408. [CrossRef]

86. Ting, V.P.; Ramirez-Cuesta, A.J.; Bimbo, N.; Sharpe, J.E.; Noguera-Diaz, A.; Presser, V.; Rudic, S.; Mays, T.J. Direct evidence for solid-like hydrogen in a nanoporous carbon hydrogen storage material at supercritical temperatures. ACS Nano 2015, 9, 8249-8254. [CrossRef] [PubMed]

87. Nigmatullin, R.R.; Baleanu, D.; Povarova, D.; Salah, N.; Habib, S.S.; Memic, A. Raman spectra of nanodiamonds: New treatment procedure directed for improved Raman signal marker detection. Math. Probl. Eng. 2013, 11. [CrossRef]

88. Dychalska, A.; Popielarski, P.; Frankow, W.; Fabisiak, K.; Paprocki, K.; Szybowicz, M. Study of CVD diamond layers with amorphous carbon admixture by Raman scattering spectroscopy. Mater. Sci. Pol. 2015, 33, 799-805. [CrossRef]

89. Namba, Y.; Heidarpour, E.; Nakayama, M. Size effects appearing in the Raman-spectra of polycrystalline diamonds. J. Appl. Phys. 1992, 72, 1748-1751. [CrossRef]

90. Liu, P.; Sun, Q.; Zhu, F.; Liu, K.; Jiang, K.; Liu, L.; Li, Q.; Fan, S. Measuring the work function of carbon nanotubes with thermionic method. Nano Lett. 2008, 8, 647-651. [CrossRef] [PubMed]

91. Yoshikawa, M.; Mori, Y.; Maegawa, M.; Katagiri, G.; Ishida, H.; Ishitani, A. Raman-scattering from diamond particles. Appl. Phys. Lett. 1993, 62, 3114-3116. [CrossRef]

92. Osswald, S.; Mochalin, V.N.; Havel, M.; Yushin, G.; Gogotsi, Y. Phonon confinement effects in the Raman spectrum of nanodiamond. Phys. Rev. B 2009, 80, 075419. [CrossRef]

93. Shin, J.K.; Lee, C.S.; Lee, K.R.; Eun, K.Y. Effect of residual stress on the Raman-spectrum analysis of tetrahedral amorphous carbon films. Appl. Phys. Lett. 2001, 78, 631-633. [CrossRef]

94. Zhou, J.H.; Sui, Z.J.; Zhu, J.; Li, P.; De, C.; Dai, Y.C.; Yuan, W.K. Characterization of surface oxygen complexes on carbon nanofibers by TPD, XPS and FT-IR. Carbon 2007, 45, 785-796. [CrossRef]

95. Liu, X.; Su, D.S.; Schlogl, R. Oxidative dehydrogenation of 1-butene to butadiene over carbon nanotube catalysts. Carbon 2008, 46, 547-549. [CrossRef]

96. Desimoni, E.; Casella, G.I.; Morone, A.; Salvi, A.M. XPS determination of oxygen-containing functional-groups on carbon-fiber surfaces and the cleaning of these surfaces. Surf. Interface Anal. 1990, 15, 627-634. [CrossRef]

97. Fan, X.M.; Yu, C.; Yang, J.; Ling, Z.; Qiu, J.S. Hydrothermal synthesis and activation of graphene-incorporated nitrogen-rich carbon composite for high-performance supercapacitors. Carbon 2014, 70, 130-141. [CrossRef]

98. Mori, Y.; Kawarada, H.; Hiraki, A. Properties of metal diamond interfaces and effects of oxygen adsorbed onto diamond surface. Appl. Phys. Lett. 1991, 58, 940-941. [CrossRef] 
99. Ghodbane, S.; Haensel, T.; Coffinier, Y.; Szunerits, S.; Steinmuller-Nethl, D.; Boukherroub, R.; Ahmed, S.I.U.; Schaefer, J.A. Hreels investigation of the surfaces of nanocrystalline diamond films oxidized by different processes. Langmuir 2010, 26, 18798-18805. [CrossRef] [PubMed]

100. Gajewski, W.; Huth, M.; Buth, F.; Nickel, B.; Stutzmann, M.; Garrido, J.A. Photoresponse and morphology of pentacene thin films modified by oxidized and reduced diamond surfaces. Phys. Rev.B 2009, 80, 235311. [CrossRef]

101. Makau, N.W.; Derry, T.E. Study of oxygen on the three low index diamond surfaces by XPS. Surf. Rev. Lett. 2003, 10, 295-301. [CrossRef]

102. Speranza, G.; Torrengo, S.; Miotello, A.; Minati, L.; Bernagozzi, I.; Ferrari, M.; Dipalo, M.; Kohn, E. XPS and UPS in situ study of oxygen thermal desorption from nanocrystalline diamond surface oxidized by different process. Diam. Relat. Mat. 2011, 20, 560-563. [CrossRef]

103. Takabayashi, S.; Okamoto, K.; Motoyama, H.; Nakatani, T.; Sakaue, H.; Takahagi, T. X-ray photoelectron analysis of surface functional groups on diamond-like carbon films by gas-phase chemical derivatization method. Surf. Interface Anal. 2010, 42, 77-87. [CrossRef]

104. Shandilya, M.; Rai, R.; Singh, J. Review: Hydrothermal technology for smart materials. Adv. Appl. Ceram. 2016, 115, 354-376. [CrossRef]

105. Funke, A.; Ziegler, F. Hydrothermal carbonization of biomass: A summary and discussion of chemical mechanisms for process engineering. Biofuels Bioprod. Biorefin.Biofpr 2010, 4, 160-177. [CrossRef]

106. Gron, L.U.; LaCroix, J.E.; Higgins, C.J.; Steelman, K.L.; Tinsley, A.S. Heck reactions in hydrothermal, sub-critical water: Water density as an important reaction variable. Tetrahedron Lett. 2001, 42, 8555-8557. [CrossRef]

107. Kurniawan, A.; Effendi, C.; Ong, L.K.; Kurniawan, F.; Lin, C.X.; Angkawijaya, A.E.; Ju, Y.H.; Ismadji, S.; Zhao, X.S. Preparation of nanoporous carbon microspheres by subcritical water carbonization and electrocapacitive study. Electrochim. Acta 2013, 111, 99-107. [CrossRef]

108. Economou, N.P.; Notte, J.A.; Thompson, W.B. The history and development of the helium ion microscope. Scanning 2012, 34, 83-89. [CrossRef] [PubMed]

109. Scipioni, L.; Stern, L.A.; Notte, J.; Sijbrandij, S.; Griffin, B. Helium ion microscope. Adv. Mater. Process. 2008, $166,27-30$.

110. Scipioni, L.; Sanford, C.A.; Notte, J.; Thompson, B.; McVey, S. Understanding imaging modes in the helium ion microscope. J. Vac. Sci. Technol. B 2009, 27, 3250-3255. [CrossRef]

111. Petrov, Y.V.; Vyvenko, O.F.; Bondarenko, A.S. Scanning helium ion microscope: Distribution of secondary electrons and ion channeling. J. Surf. Investig. X-ray Synchrotron Neutron Tech. 2010, 4, 792-795. [CrossRef]

112. Sanford, C.; Notte, J.; Scipioni, L.; McVey, S.; Hill, R.; Sijbrandij, S.; Farkas, L. Advances in high resolution helium ion microscope (HIM) imaging. Microsc. Microanal. 2009, 15, 654-655. [CrossRef]

113. Bell, D.C. Contrast mechanisms and image formation in helium ion microscopy. Microsc. Microanal. 2009, 15, 147-153. [CrossRef] [PubMed]

114. Cohen-Tanugi, D.; Yao, N. Superior imaging resolution in scanning helium-ion microscopy: A look at beam-sample interactions. J. Appl. Phys. 2008, 104. [CrossRef]

115. Fox, D.; Zhou, Y.B.; O'Neill, A.; Kumar, S.; Wang, J.J.; Coleman, J.N.; Duesberg, G.S.; Donegan, J.F.; Zhang, H.Z. Helium ion microscopy of graphene: Beam damage, image quality and edge contrast. Nanotechnology 2013, 24, 33. [CrossRef] [PubMed]

116. Ohya, K.; Yamanaka, T.; Inai, K.; Ishitani, T. Comparison of secondary electron emission in helium ion microscope with gallium ion and electron microscopes. Nucl. Instrum. Methods Phys. Res. Sect B Beam Interact. Mater. At. 2009, 267, 584-589. [CrossRef]

117. Ward, B.W.; Notte, J.A.; Economou, N.P. Helium ion microscope: A new tool for nanoscale microscopy and metrology. J. Vac. Sci. Technol. B 2006, 24, 2871-2874. [CrossRef]

118. Sijbrandij, S.; Notte, J.; Sanford, C.; Hill, R. Analysis of subsurface beam spread and its impact on the image resolution of the helium ion microscope. J. Vac. Sci. Technol. B 2010, 28, C6F6-C6F9. [CrossRef]

119. Chipara, D.M.; Chipara, A.C.; Chipara, M. Raman spectroscopy of carbonaceous materials: A concise review. Spectroscopy 2011, 26, 42-47.

120. Dresselhaus, M.S.; Jorio, A.; Hofmann, M.; Dresselhaus, G.; Saito, R. Perspectives on carbon nanotubes and graphene Raman spectroscopy. Nano Lett. 2010, 10, 751-758. [CrossRef] [PubMed] 
121. Retzko, I.; Unger, W.E.S. Analysis of carbon materials by X-ray photoelectron spectroscopy and X-ray absorption spectroscopy. Adv. Eng. Mater. 2003, 5, 519-522. [CrossRef]

122. Lennon, D.; Lundie, D.T.; Jackson, S.D.; Kelly, G.J.; Parker, S.F. Characterization of activated carbon using X-ray photoelectron spectroscopy and inelastic neutron scattering spectroscopy. Langmuir 2002, 18, 4667-4673. [CrossRef]

123. Ray, S.C.; Tetana, Z.N.; Erasmus, R.; Mathur, A.; Coville, N.J. Carbon spheres for energy applications: Raman and X-ray photoemission spectroscopy studies. Int.l J. Energy Res. 2014, 38, 444-451. [CrossRef]

124. Petit, T.; Arnault, J.C.; Girard, H.A.; Sennour, M.; Bergonzo, P. Early stages of surface graphitization on nanodiamond probed by X-ray photoelectron spectroscopy. Phys. Rev. B 2011, 84, 233407. [CrossRef]

125. Takabayashi, S.; Okamoto, K.; Shimada, K.; Motomitsu, K.; Motoyama, H.; Nakatani, T.; Sakaue, H.; Suzuki, H.; Takahagi, T. Chemical structural analysis of diamondlike carbon films with different electrical resistivities by X-ray photoelectron spectroscopy. Jpn. J. Appl. Phys. 2008, 47, 3376-3379. [CrossRef]

126. Abbas, M.; Wu, Z.Y.; Zhong, J.; Ibrahim, K.; Fiori, A.; Orlanducci, S.; Sessa, V.; Terranova, M.L.; Davoli, I. $\mathrm{X}$-ray absorption and photoelectron spectroscopy studies on graphite and single-walled carbon nanotubes: Oxygen effect. Appl. Phys. Lett. 2005, 87. [CrossRef]

127. Gordeev, S.K.; Grechinskaya, A.V.; Danishevskii, A.M.; Smorgonskaya, E.A.; Shchukarev, A.V. Study of bonding in nanoporous carbon by X-ray photoelectron spectroscopy. Mol. Mater. 2000, 13, 355-360.

128. Yang, D.; Velamakanni, A.; Bozoklu, G.; Park, S.; Stoller, M.; Piner, R.D.; Stankovich, S.; Jung, I.; Field, D.A.; Ventrice, C.A.; et al. Chemical analysis of graphene oxide films after heat and chemical treatments by $\mathrm{X}$-ray photoelectron and micro-Raman spectroscopy. Carbon 2009, 47, 145-152. [CrossRef]

129. Takahiro, K.; Terai, A.; Oizumi, S.; Kawatsura, K.; Yamamoto, S.; Naramoto, H. Amorphization of carbon materials studied by X-ray photoelectron spectroscopy. Nucl. Instrum. Methods Phys. Res. Sect. B Beam Interact. Mater. At. 2006, 242, 445-447. [CrossRef]

130. Achour, A.; Vizireanu, S.; Dinescu, G.; Le Brizoual, L.; Djouadi, M.A.; Boujtita, M. Electrochemical anodic oxidation of nitrogen doped carbon nanowall films: X-ray photoelectron and micro-Raman spectroscopy study. Appl. Surf. Sci. 2013, 273, 49-57. [CrossRef]

131. Barty, A.; Marchesini, S.; Chapman, H.N.; Cui, C.; Howells, M.R.; Shapiro, D.A.; Minor, A.M.; Spence, J.C.H.; Weierstall, U.; Ilavsky, J.; et al. Three-dimensional coherent X-ray diffraction imaging of a ceramic nanofoam: Determination of structural deformation mechanisms. Phys. Rev. Lett. 2008, 101, 055501. [CrossRef] [PubMed]

132. Jablonski, A.; Tilinin, I.S.; Powell, C.J. Mean escape depth of signal photoelectrons from amorphous and polycrystalline solids. Phys. Rev. B 1996, 54, 10927-10937. [CrossRef]

133. Jablonski, A. Elastic photoelectron scattering effects in the XPS analysis of stratified samples. J. Phys. D Appl. Phys. 2012, 45, 31. [CrossRef]

134. Nefedov, V.I. Photoelectron elastic scattering effects in XPS. J. Electron Spectrosc. Relat. Phenom. 1999, 100, 1-15. [CrossRef]

135. Jablonski, A.; Powell, C.J. Relationships between electron inelastic mean free paths, effective attenuation lengths, and mean escape depths (vol 100, pg 137, 1999). J. Electron Spectrosc. Relat. Phenom. 2000, 107, 201. [CrossRef]

136. Tilinin, I.S.; Jablonski, A.; Lesiakorlowska, B. Mean escape depth of signal photoelectrons from amorphous and polycrystalline solids. Acta Phys. Pol. A 1994, 86, 845-852. [CrossRef]

137. Hovis, J.S.; Hamers, R.J.; Greenlief, C.M. Preparation of clean and atomically flat germanium(001) surfaces. Surf. Sci. 1999, 440, L815-L819. [CrossRef]

138. Wang, B.; Ma, Y.F.; Wu, Y.P.; Li, N.; Huang, Y.; Chen, Y.S. Direct and large scale electric arc discharge synthesis of boron and nitrogen doped single-walled carbon nanotubes and their electronic properties. Carbon 2009, 47, 2112-2115. [CrossRef]

139. Reinke, P.; Francz, G.; Oelhafen, P.; Ullmann, J. Structural changes in diamond and amorphous carbon induced by low-energy ion irradiation. Phys. Rev. B 1996, 54, 7067-7073. [CrossRef]

140. Onoe, J.; Nakao, A.; Takeuchi, K. XPS study of a photopolymerized c-60 film. Phys.l Rev. B 1997, 55, 10051-10056. [CrossRef]

(C) 2017 by the authors. Licensee MDPI, Basel, Switzerland. This article is an open access article distributed under the terms and conditions of the Creative Commons Attribution (CC BY) license (http://creativecommons.org/licenses/by/4.0/). 